\title{
FRANCO-BRITISH RELATIONS AND THE QUESTION OF CONSCRIPTION IN BRITAIN, 1938-1939
}

\begin{abstract}
This article examines the relationship interaction between the French campaign for the introduction of British conscription during 1938-39 and the ebbs and flows of British public opinion on the same issue. In particular, it will demonstrate how French pressure for conscription varied in intensity depending on their perceptions of British opinion on the subject. It was this interaction between diplomatic and domestic pressures that ultimately compelled the British government to introduce conscription in April 1939. Furthermore, the issue of conscription also sheds light on the wider issue of Franco-British relations, revealing how French foreign policy was neither dictated by an 'English Governess' nor pursued independently of Great Britain.
\end{abstract}

When Neville Chamberlain announced the introduction of conscription to the House of Commons on 26 April 1939 he not only reneged on previous promises but deviated from the traditional British aversion to peacetime compulsory service. Chamberlain defended himself by arguing that current international tensions could not be described as 'peace-time in any sense in which the term could fairly be used'. Nonetheless, introducing conscription - albeit in a limited form ${ }^{2}$ - was alien to British tradition. How, therefore, can the decision be explained? What motivated the government to take such a step? This article sheds new light on the British decision to implement conscription in April 1939, moving beyond existing analyses by showing that the decision was motivated not only by a fusion of domestic and international pressures but by the interaction of the two. More specifically, contends that French pressure for British conscription ebbed and flowed in direct correlation to the French government's perceptions of the British public's attitude towards compulsory military service. In particular, the growing public demand for conscription both in the immediate aftermath of the September 1938 Munich Agreement and again after the German occupation of the rump Czech state in March 1939 encouraged the French to intensify their official interventions.

In addition, the conscription question can be used as a 'core sample' with which to analyse the wider issue of Franco-British relations during the final months of peace. ${ }^{3}$

\footnotetext{
${ }^{1}$ Hansard, Parliamentary Debates, $5^{\text {th }}$ Series, 346 House of Commons Debates, col. 1152.

2 The form of conscription introduced applied only to men aged 20 and 21.

${ }^{3}$ This use of a 'core sample' borrows from Keith Neilson, who uses Anglo-Soviet relations as a 'core sample' for analysing the wider issue of British strategic foreign policy in the inter-war years. Britain, the Soviet Union and the Collapse of the Versailles Settlement, 1919-1941, (Cambridge: Cambridge University Press, 2006).
} 
French pressure for conscription certainly shows that the notion of an 'English Governess' does not stand up to scrutiny. ${ }^{4}$ However, the counter argument is also problematic. Talbot Imlay's suggestion that France adopted a politique de fermeté independently of Britain is persuasive but not clear-cut. ${ }^{5}$ The conscription 'core sample' reveals that the reality was more ambiguous: although the French government undoubtedly became more assertive, it did not act entirely independently of Britain, always paying careful attention to British public opinion. Reports from the London embassy during 1938-9 indicated that British public opinion was sympathetic to the firmer foreign policy adopted by Paris and, moreover, was prepared to increase the degree of British commitment to France, even at the cost of conscription.

Chamberlain's decision to introduce conscription in April 1939 has been attributed to French demands, domestic pressures, or a combination of the two. Talbot Imlay and Anthony Adamthwaite both suggest that French pressure was critical, whilst N. J. Crowson and Michael Dockrill emphasise the increased demands from within the Conservative Party ${ }^{6}$. For Peter Dennis, Chamberlain's decision was simultaneously 'a political gesture to the French' and a response to growing press and parliamentary pressure at home. Brian Bond concurs, suggesting that Chamberlain was 'obliged to bow to these combined diplomatic and domestic pressures'. ${ }^{7}$ However, neither Dennis nor Bond attempt to tease out the links between French pressure and the British press and political campaign for conscription during 1938-9. This article seeks to do just that, illustrating how France's demand for a British 'effort du sang' was contingent upon their

\footnotetext{
${ }^{4}$ For more on the notion of an 'English Governess' controlling the direction of French foreign policy, see François Bédarida, 'La "gouvernante anglaise"”, in René Rémond and Janine Bourdin (eds.), Édouard Daladier, chef de gouvernement : avril 1938-septembre 1939, (Paris: Presses de la FNSP, 1977), 228-240, and John Herman, The Paris Embassy of Sir Eric Phipps: Anglo-French Relations and the Foreign Office, 1937-1939, (Brighton: Sussex Academic Press, 1998), 90-93.

5 Talbot Imlay, 'The Making of the Anglo-French Alliance, 1938-39', in Martin S. Alexander and William J. Philpott, eds., Anglo-French Defence Relations Between the Wars, (Basingstoke: Palgrave Macmillan, 2002), 92120.

${ }^{6}$ Imlay, Facing the Second World War, 92; Anthony Adamthwaite, France and the Coming of the Second World War, 1936-1939, (London: Frank Cass, 1977), 245-263; N. J. Crowson, Facing Fascism: The Conservative Party and the European Dictators, 1935-1940, (London: Routledge, 1997), pp. 147-167; idem., 'The Conservative Party and the Call for National Service, 1937-39: Compulsion versus Voluntarism', Contemporary Record, 9:3 (1995), 507-528; Michael Dockrill, British Establishment Perspectives on France, 1936-40, (Basingstoke: Macmillan, 1999), 133.

${ }^{7}$ Peter Dennis, Decision by Default: Peacetime Conscription and British Defence, 1919-1939 (London: Routledge \& Kegan Paul, 1972), 2; Brian Bond, British Military Policy Between the Two World Wars (Oxford: Clarendon Press, 1980), 308-9.
} 
perceptions of British public opinion. That is, official French interventions regarding conscription were timed carefully to exploit a seemingly favourable climate of British public opinion.

During 1938-9, British public opinion became increasingly favourable towards peacetime conscription, especially after the Munich Agreement and after Hitler marched into Prague in March 1939. Simultaneously, the French government became more assertive, stepping up their efforts to secure a greater British military commitment to the continent. Crucially there is compelling circumstantial evidence to suggest that these efforts were inspired, at least in part, by perceptions of British public and press opinion. After Munich, reports from the French ambassador in London, Charles Corbin, indicated growing public support for conscription. Corbin's frequent reports, which formed the basis of the Quai d'Orsay's understanding of British opinion, were based largely on a reading of a cross-section of the mainstream British press. During the autumn of 1938, Corbin rightly noted that the conservative newspapers, notably those owned by Lord Beaverbrook, urged the introduction of conscription. Interestingly, this press campaign undermines the argument that the National Government manipulated the press, as several conservative journals had few qualms about canvassing support for a policy that Chamberlain clearly opposed. ${ }^{8}$ Unsurprisingly, Paris detected a fissure between the British government and public, thus encouraging the French government to intensify their official pressure for London to introduce conscription.

The French campaign for British conscription has already been well-documented, and British sources certainly support Imlay's contention that conscription was 'aimed in large part at reassuring the French'. ${ }^{9}$ The foreign office feared that failing to introduce compulsory service might prove disastrous for French morale, even causing the French side of the entente to collapse altogether. On 1 November 1938, the foreign secretary, Lord Halifax, warned the British ambassador in Paris, Sir Eric Phipps, that France might even 'turn so defeatist as to give up the struggle of maintaining adequate defences even for the safety of Metropolitan France'. ${ }^{10}$ In light of such fears, conscription was seen as a means for assuaging French concerns, providing tangible proof of a British continental commitment. However, impetus for conscription was not confined to official diplomatic

\footnotetext{
8 The argument that Chamberlain's government manipulated the press has been made by Richard Cockett, Twilight of Truth: Chamberlain, Appeasement \& the Manipulation of the Press, (London: Weidenfeld and Nicolson, 1989), and Anthony Adamthwaite, 'The British Government and the Media, 1937-1938', Journal of

Contemporary History, 18:2 (1983), 281-297.

${ }^{9}$ Imlay, Facing the Second World War, 92.

${ }^{10}$ Halifax to Phipps, 1 Nov. 1938, The National Archives (TNA), FO 800/311.
} 
pressure from France, as the press campaign in Britain clearly revealed. Indeed, as Michael Howard has argued, Britain's increasingly continental outlook 'did not outrun public opinion'. 11

That British opinion was apparently one step ahead of their government with regard to conscription was certainly noted by the French embassy in London. Of course, one must acknowledge that embassy staff had ulterior motives for portraying a growing desire in Britain to resist the dictators by force, particularly after Munich. As Yvon Lacaze has argued, Corbin 'sought to discern an evolution in British opinion towards firmness', thus helping to strengthen the hand of those in Paris who favoured a policy of resistance over foreign minister Georges Bonnet's policy of retreat. ${ }^{12}$ Indeed, Corbin was hostile to appeasement and, as John Herman has noted, this conviction was strengthened by his friendship 'with Churchill, Eden, Amery, Duff Cooper and especially Vansittart'. ${ }^{13}$ In addition, any indication of a growing firmness in Britain helped alleviate concerns regarding domestic opinion in France. Throughout the summer of 1938, French opinion had become increasingly anxious about the degree of support that would be forthcoming from Britain in the event of a Franco-German conflict. As Lacaze has remarked, French newspapers during the critical weeks of September 1938 'insisted more than ever on the Franco-British entente. ${ }^{14}$

To be sure, the French embassy represented British public opinion in such a way as to undermine appeasement and assuage the anxieties of public opinion in France. Nevertheless, this must not blind us to the fact that British opinion after Munich was evolving dramatically in favour of compulsory national service. As recently as the start of 1938, longstanding British hostility to continental entanglements continued to suggest that a large-scale continental force was both unnecessary and impractical. Furthermore, memories of the last war rendered the public suspicious of sending troops to the continent, evoking Paschendaele and the Somme, and the slaughter of hundreds of

\footnotetext{
${ }^{11}$ Michael Howard has argued that Britain's increasingly continental outlook 'did not outrun public opinion', The Continental Commitment: The Dilemmas of British Defence Policy in the Era of Two World Wars, (London: Maurice Temple Smith Ltd., 1972), 121-46.

${ }^{12}$ Yvon Lacaze, 'Daladier, Bonnet and the Decision-Making Process during the Munich Crisis, 1938', in Robert Boyce (ed.), French Foreign and Defence Policy, 1918-1940: The decline and fall of a great power, (London: Routledge, 1998), 227. For more on the orientation of French foreign policy after Munich, see Imlay, 'The Making of the Anglo-French Alliance', 92-120, and Robert Young, 'The Aftermath of Munich: The Course of French Diplomacy, October 1938 - March 1939', French Historical Studies, Vol. 8 no. 2 (1973), 305-322. ${ }^{13}$ John Herman, The Paris Embassy of Sir Eric Phipps: Anglo-French Relations and the Foreign Office, 1937-1939, (Brighton: Sussex Academic Press, 1998), 27. The anti-appeasement stance of the French Embassy in London also comes across in Girard de Charbonnière's Les plus évitable de toutes les guerres, (Paris: Albatros, 1985).

${ }^{14}$ Lacaze, L'opinion publique française et la crise de Munich, 259.
} 
thousands of young men; 'No more Sommes' was the watchword in the interwar period. ${ }^{15}$ British strategy did not, however, overlook continental Europe. ${ }^{16}$ Indeed, the advent of Nazism demanded that Britain take her continental commitment seriously. As the then prime minister, Stanley Baldwin, told the Commons in July 1934: "When you think of the defence of England you no longer think of the chalk cliffs of Dover; you think of the Rhine'. ${ }^{17}$ Moreover, advancements in aerial warfare directly threatened Britain's security, undermining the security provided by island status. The integrity of France and the Low Countries was therefore crucial for Britain; should these countries fall into hostile hands, aerial raids on Britain would be increasingly damaging and frequent. ${ }^{18}$

Nevertheless, the concept of 'limited liability' prevailed in the mid-1930s. ${ }^{19}$ The National Government embraced this viewpoint, while the Labour opposition had always been hostile to large-scale continental commitments. ${ }^{20}$ Moreover, a latent distrust of France continued to inform perceptions. For many in Britain, France's quest for sécurité was an almost paranoid obsession, and French intransigence was often considered to have legitimized German revanchism. ${ }^{21}$ There was also a growing awareness that modern warfare had progressed since 1914-18, and that military doctrine must adapt accordingly. The size of the army was no longer paramount, as technological advancements meant that future conflicts would be decided not by sheer volume of troops but by their mobility and standard of equipment. Therefore, a small professional army, equipped to the most advanced standards of the day, was potentially more potent than a large, illequipped and inadequately trained conscript force. ${ }^{22}$

\footnotetext{
${ }^{15}$ William Philpott, 'The General Staff and the Paradoxes of Continental War', in David French and Brian Holden Reid, eds., The British General Staff: Reform and Innovation, c.1890-1939, (London: Frank Cass, 2002), 95-111.

${ }^{16}$ J. P. Harris, 'The British General Staff and the Coming of War, 1933-39', in French and Holden Reid, eds., The British General Staff, 175-191, at 190.

${ }^{17}$ Cited in Bond, British Military Policy, 209.

${ }^{18}$ Harris, 'The British General Staff and the Coming of War, 1933-39', 175-91.

${ }^{19}$ Howard, The Continental Commitment, 96-120; Bond, British Military Policy, 209-29.

${ }^{20}$ Jerry H. Brookshire, “'Speak for England”, Act for England: Labour's Leadership and British National Security Under the Threat of War in the Late 1930s', European History Quarterly, Vol. 29, no. 2 (1999), 251 87.

${ }^{21}$ In late 1935, Sir Henry Pownall, argued that German revanchism could have been avoided had she 'been properly treated and allowed some revision of at least the disarmament clauses of the Treaty. But the chief blame for the failure to do that must surely lie with the French'. Cited in Brian Bond, ed., Chief of Staff: The Diaries of Lieutenant-General Sir Henry Pownall, vol. 1, 1933-1940, (London: L. Cooper, 1972), 55. More generally, French preponderance in continental Europe power upset the British strategy of maintaining a balance of power. See B. J. C. McKercher, 'The Foreign Office, 1930-39: Strategy, Permanent Interests and National Security', Contemporary British History, Vol. 18, no. 3 (2004), 87-109, at 95.

${ }^{22}$ David French, Raising Churchill's Army: The British Army and the War Against Germany, 1919-1945, (Oxford: Oxford University Press, 2000), 15.
} 
These factors underpinned the concept of limited liability, and Chamberlain was a committed advocate. In March 1937, he was convinced that 'we shall never again send to the continent an army on the scale of that which we put into the field in the Great War'. Chamberlain's appointee as war minister, Leslie Hore-Belisha, concurred: 'our army should be organised to defend this country and the empire ..., to organise it with a military prepossession in favour of a continental commitment is wrong. ${ }^{23}$ In a defence paper in February 1938, Hore-Belisha recommended that 'our allies should be left in no doubt as to the possibilities of direct assistance on our part'. ${ }^{24}$ Under Chamberlain's premiership, the concept of 'limited liability' appeared to have reached its zenith. Indeed, Michael Howard has suggested that the concept had essentially become a policy 'of no liability at all ${ }^{25}$ Such was the British position by the time Édouard Daladier formed a new French government in April 1938. For Daladier, with his wealth of experience at the French war ministry, obtaining further British military assistance in the event of war was essential.

\section{II}

In February 1938, the chief of the French general staff, Maurice Gamelin summarized the British military commitment to France. In the event of a European war, he noted, British assistance would be 'insignificant, more or less from the start'. ${ }^{26}$ Consequently, Daladier's forthcoming visit to London in April 1938 was seen in Paris as an opportunity to ask Britain to take, 'measures permitting them to despatch an expeditionary force in proportion to their population', even at 'the cost of conscription'. ${ }^{27}$ The British government, however, were obdurate. As Duff Cooper remarked in his diary, the cabinet had decided to 'tell the French that the prospect of our sending a force to the continent in the event of war is too remote to be worth discussing'. ${ }^{28}$ Consequently, Halifax re-

\footnotetext{
${ }^{23}$ Chamberlain to Liddell-Hart, 8 Mar. 1937, cited in Alex Danchev, Alchemist of War: The Life of Basil Liddell-Hart, (London: Phoenix Giant, 1999), 191; Hore-Belisha to Chamberlain, 23 Nov. 1937, cited in Bond, British Military Policy, 253.

24 'The Organisation of the Army for its rôle in war', Cabinet paper by Hore-Belisha, 10 Feb. 1938, TNA, WO 33/1502.

${ }^{25}$ Howard, The Continental Commitment, 117.

${ }^{26}$ Gamelin to Daladier, 'Les données actuelles du problème militaire française', 11 Feb. 1938, Archives Nationales (AN), Fonds Daladier, 496 AP/30, 4 DA 3 dr. 1 sdra.

${ }^{27}$ Note sur la collaboration militaire franco-britannique, 24 Apr. 1938, AN, Fonds Daladier, 496 AP/35, 4 DA 8 Dr. 3 sdrb.

${ }^{28}$ John Julius Norwich (ed.), The Duff Cooper Diaries, 1915-1951, (London: Phoenix, 2006), diary entry for 22 Apr. 1938, 246.
} 
iterated to the French that Britain could only contribute two divisions. ${ }^{29}$ The French voiced little dissent. Not only had British obstinacy had left little room for manoeuvre, but British public opinion endorsed their government's position. As Corbin noted, the British press remained 'alarmed' by the prospect of peacetime conscription. ${ }^{30}$

However, the rapid evolution of international events in 1938 forced the British public to re-evaluate continental commitments. The Czechoslovakian crisis exposed British military shortcomings, which were readily acknowledged to have contributed to the Munich capitulation. The Daily Mail warned that work must be done so that 'no gaps remain to be filled at the last moment'. ${ }^{31}$ Cabinet members perceived a change in the public mood. The home secretary, Sir John Simon, detected a increased willingness to serve, the public now realising 'the extent of the sacrifice that must be made for Britain'. ${ }^{32}$ The specific issue of conscription was also raised, particularly in the Beaverbrook newspapers. The Daily Express argued that Chamberlain must 'change his views on conscription', whilst Duff Cooper, who resigned from the cabinet in protest at Munich, wrote in the Evening Standard that 'conscription is the cry that leaps to all men's mouths' ${ }^{33}$ For Beaverbrook, there was no contradiction between advocating isolationism and conscription. 'The Isolationists have always supported preparations for defence', he wrote to one of his many correspondents, 'and the Isolationists are in favour of compulsory military service for the youth of the country, ${ }^{34}$

Elsewhere in the press, a Daily Mail ballot revealed that a majority favoured conscription in the immediate aftermath of Munich, although opinion became more divided as tensions eased in subsequent days. ${ }^{35}$ Nevertheless, a poll conducted by the British Institute of Public Opinion (BIPO), published in The News Chronicle on 19 October, showed $78 \%$ in favour of a national register, including the majority of opposition supporters. As Corbin reported, the press campaign was echoed in Parliament, with a growing clamour for, 'if not conscription pure and simple, at least a form of "national service"”. Furthermore, remarked Corbin, the BIPO poll indicated that

\footnotetext{
${ }^{29}$ Documents on British Foreign Policy (DBFP), 3rd ser., I, no. 164.

${ }^{30}$ Corbin to Bonnet, 5 Jun. 1938, Ministère des Affaires Étrangères (MAE), Série Z, Grande-Bretagne, no. 237.

${ }^{31}$ Daily Mail, editorial, 3 Oct. 1938.

32339 H. C. Deb. 5s, col. 308.

${ }^{33}$ Daily Express, editorial, 7 Oct. 1938; Duff Cooper, Evening Standard, 19 Oct. 1938.

${ }^{34}$ Beaverbrook to James Agate, 5 Oct. 1938, Beaverbrook Papers, House of Lords Record Office, $\mathrm{BBK} / \mathrm{B} / 292$.

35 The Daily Mail launched the ballot on 12 Oct. 1938, and published the results on 28 Oct. 1938. The Daily Mail avoided stating an editorial preference, merely seeking to 'gain those opinions [of their readers], and present the weight of them to the authorities', (12 Oct. 1938).
} 
the majority of the public were 'favourable to the rapid organisation of a national register'. ${ }^{36}$ French hopes were raised that the British government would now enhance their level of commitment to France, and Paris thus seized the opportunity to intensify their official interventions advocating the introduction of conscription.

One particularly effective way of stressing the need for enhanced British commitment was perpetuating British fears of French defeatism, convincing London that the lack of British support unsettled French public opinion. Of course, this was not entirely fabrication, as Phipps was quite accurate in reporting that the French press had, throughout the Czechoslovakian crisis, unanimously 'declared that Anglo-French cooperation was essential'. ${ }^{37}$ Furthermore, there were compelling political and military imperatives for ensuring effective co-operation between the two democracies. At the Radical party congress in late October, Georges Bonnet declared the cornerstone of his foreign policy to be the Franco-British alliance, ${ }^{38}$ whilst a conseil supérieur de la défense nationale (CSDN) note of 12 October concluded that France must be in close accord with Britain' in order to 'oppose further German strikes in Eastern Europe' ${ }^{39}$ For Phipps, French attitudes to the entente bordered on desperation. France, he reported, 'attaches almost pathetic importance' to Britain. ${ }^{40}$

Phipps's comments reflected a growing fear within British diplomatic circles partly fostered by Paris - that French opinion was flirting with isolationism and even defeatism. Further concerns surfaced in a memorandum by the British military attaché in Paris, Colonel William Fraser, reporting the views of Général Henri Dentz, the deputy chief of the French general staff. Almost certainly aware of the growing press demand in Britain for conscription, Dentz seized the opportunity to heighten British fears of potential French isolationism. Britain, he warned, must 'take care of French public opinion. France does not intend to allow Britain to fight her battles with French soldiers'. In the foreign office, alarm bells were ringing. 'We must', warned Halifax, 'be careful to keep the French very close'. ${ }^{41}$

\footnotetext{
${ }^{36}$ Corbin to Bonnet, 13 Oct. and 24 Oct. 1938, MAE, Série Z, Grande-Bretagne, no. 280.

${ }_{37}$ Phipps to Halifax, 3 Oct. 1938, TNA, FO 371/21767/C11502/4770/18.

${ }^{38}$ Bonnet's speech to the Radical Party Congress, 29 Oct. 1938, cited in Le Temps, 30 Oct. 1938.

${ }^{39}$ CSDN, 'Note sur la situation actuelle', 12 Oct. 1938, Service Historique de l'Armée de Terre (SHAT),

$5 \mathrm{~N} 579$, dossier 1. I am grateful to Lora Gibson of the University of Aberystwyth for the reference to this document.

40 Phipps to Halifax, 10 Nov. 1938, TNA, FO 371/21603/C13846/101/17.

${ }^{41}$ Memorandum by Colonel Fraser, 12 Oct. 1938; Orme-Sargent minute, 21 Oct. 1938; Halifax minute, 23 Oct. 1938, TNA, FO 371/21785/C12144/11169/18. See also Herman, The Paris Embassy of Sir Eric Phipps, 133-4.
} 
Dentz's warnings were not isolated, with reports from the Paris embassy and numerous British consuls evoking 'undercurrents of defeatism'. ${ }^{42}$ For Halifax, a trip to Paris in late November was essential, if only to reassure the French. Direct conversations with the British prime minister and foreign secretary offered the French ministers another opportunity 'to ask Great Britain to intensify and accelerate her military effort', particularly vis-à-vis 'her land forces for the continent'. ${ }^{43}$ Encouraged by post-Munich British press commentary, Corbin urged Paris not to allow Chamberlain to evade the issue. 'Must we wait six months' asked Corbin, 'as in 1914, for the "first hundred thousand" to make their appearance on our soil?' By contrast, the French military attaché in London, Général Lelong, was unconvinced that British opinion had evolved so dramatically, reminding Paris that many in Britain considered conscription unnecessary, retaining an almost illusory faith in French defensive capabilities: 'They think that the French army, supported by the Maginot Line, must be capable of holding ... indefinitely! ${ }^{44}$

Nevertheless, Lelong concurred with Corbin that France must demand a greater military contribution from Britain, perhaps motivated by the attitude of the British General Staff. As Imlay has noted, Major-General Sir Henry Pownall, the Director of Military Operations and Intelligence, instructed Fraser 'to prompt the French to press the issue of the BEF's size during the visit of the British ministers' ${ }^{45}$ Daladier duly did so, arguing that two divisions were wholly inadequate. 'More divisions were needed', he argued, 'and as far as possible they should be motorised'. His appeal, however, fell on deaf ears, Chamberlain quickly retorting that home defence must remain the British priority. ${ }^{46}$ The prime minister's intransigence caused frustration on both sides of the channel. Pownall, who had hoped that Chamberlain and Halifax would return from Paris 'more receptive to the idea of sending troops to France', subsequently lamented that the French had not pressed harder. ${ }^{47}$

\footnotetext{
42 Phipps to Halifax, 12 Oct. 1938, DBFP, 3rd ser., I, no. 187; Report from the British Consul in Bordeaux, 13 Oct. 1938, TNA, FO 371/21613/C12852/1050/17.

$433^{\circ}$ Bureau: Note concernant les demandes à présenter au Gouvernement britannique à l'action militaire terrestre, 23 Nov. 1938; Note, Section de Défense nationale, 22 Nov. 1938, AN, Fonds Daladier 496 AP/11, 2 DA 4 Dr. 2, sdra.

${ }^{44}$ Corbin to Bonnet, 8 Nov. 1938, AN, Fonds Daladier, 496 AP/10, 2 DA 4 Dr. 3, sdra; Lelong: 'Étude sur la participation de l'Angleterre dans l'éventualité d'une action commune franco-britannique en cas de guerre', 8 Nov. 1938, AN, Fonds Daladier, 496 AP/35, 4 DA 8 Dr. 3 sdrb.

${ }^{45}$ Imlay, 'The Making of the Anglo-French Alliance', 110.

${ }^{46}$ Record of Anglo-French Conversations, 24 Nov. 1938, DBFP, 3rd ser., III, no. 325.

${ }^{47}$ Bond, ed., Chief of Staff, diary entries for 14 and 28 Nov. 1938, 170-1.
} 
In choosing not to press too hard - at least for the moment - the French had one eye on British opinion. As tensions eased after Munich, press discussion of conscription waned, and those newspapers most favourable to conscription were also opposed to a large expeditionary force. Moreover, the spectre of French defeatism perpetuated the image of a fractured and divided country, playing into the hands of the isolationists who questioned the wisdom of committing British forces to the defence of France. For the Daily Express, such a commitment was akin to 'pledging the whole youth of Great Britain to a war for France's frontiers'. The Daily Mirror was similarly sceptical: 'What, another big army of fine young men for idiotic and arrogant dud generals to drive to death and destruction?' The anticipated leftist opposition was also freely expressed, the far-left repeating the old arguments that military conscription would be the precursor to industrial conscription. The Daily Worker claimed that the 'working class of Britain will not submit to be regimented while capitalists are left free to pick our pockets.' ${ }^{48}$ Furthermore, an upsurge in French domestic unrest, culminating in the general strike of 30 November, undermined British confidence in her ally. As Corbin warned, the French domestic situation 'cannot be an excuse for Great Britain to limit her contribution to the system of Franco-British defence'. ${ }^{49}$

Nevertheless, sections of the British government were more amenable to conscription. Halifax recommended a compulsory register to the cabinet on 14 November, impressed by intelligence reports suggesting that such a measure would impress Hitler. ${ }^{50}$ Although Chamberlain's counter-argument - that it would be of little practical value - prevailed, reports of potential French defeatism reverberated. Phipps noted a 'widespread propaganda in France [...] to the effect that in a major emergency France can only rely on Great Britain "to fight to the last Frenchman". ${ }^{11}$ At the same time, the French government intensified their efforts to extract a declaration of FrancoBritish solidarity. For Paris, the shouts of 'Corsica, Tunis, Nice' in the Italian Chamber on 30 November reinforced the need for further British assurances. Moreover, the

\footnotetext{
48 Daily Express, editorial, 26 Nov. 1938; Daily Mirror, 26 Nov. 1938; Daily Worker, editorial, 28 Oct. 1938.

${ }^{49}$ Corbin to Bonnet, 26 Nov. 1938, MAE, Série Z, Grande-Bretagne, no. 291.

${ }^{50}$ Hitler was alleged to have claimed: 'If the English have not got universal conscription by the spring of 1939 they may consider their world empire as lost'. Cabinet Committee on Foreign Policy, 14 Nov. 1938, TNA, CAB $27 / 624$.

${ }^{51}$ Phipps report on the present situation in France (prior to the visit to Paris of Chamberlain and Halifax), 16 Nov. 1938, TNA, FO 371/21600/C14025/55/17.
} 
Italian demands appeared to unite French opinion, persuading London that French domestic unrest was dissipating, persuading even the isolationists that France was an ally worthy of increased British support.

The French government's firm response to the Italian demands was, as JeanBaptiste Duroselle notes, approved by 'the quasi-unanimity of French public opinion'. ${ }^{52}$ Coupled with the relative failure of the general strike, the societal upheaval of previous years gave way to increased unity, which was warmly welcomed by the British press. ${ }^{53}$ However, Chamberlain's stance remained worrying. When news emerged that Chamberlain intended to visit Rome in January, many in France suspected that he was seeking to mediate to the detriment of French interests. ${ }^{54}$ Chamberlain's intentions were also questioned at home, where many were convinced that Britain's priority must be assuaging French concerns rather than appeasing Mussolini. ${ }^{55}$ Duff Cooper argued that Britain must be capable of putting into the field a respectable arm of at least ten or twelve divisions within a month or two of the outbreak of war'. Vansittart concurred, warning Halifax of 'a very wide-spread feeling of discontent with us in France,. ${ }^{56}$

Vansittart's views were lent credence by Fraser's report of 22 December, warning of the persistent French suspicion that Britain sought 'to fight her battles on the continent with French soldiers'. The following day, he conveyed the concerns of the French general staff regarding 'our refusal to accept the necessity for having an effective army ${ }^{57}$ In Paris, Bonnet again played the defeatism card: 'it would be dreadful for the morale of the French army for Frenchmen to feel that they would be alone for so long before having the support of their allies'. ${ }^{58} \mathrm{~A}$ fusion of such reports, coupled with representations of a British public opinion increasingly keen to strengthen the AngloFrench alliance, added impetus to arguments in favour of compulsory service. In early 1939, rumours of an imminent German strike in Western Europe had even more telling repercussions.

\footnotetext{
52 Jean-Baptiste Duroselle, La décadence, (Paris: Imprimerie Nationale, 1979), 391. Phipps reported how 'I have never known French public opinion so unanimous as it is against Italy', Phipps to Halifax, 21 Dec. 1938, TNA, FO 371/23791/R55/7/22.

${ }^{53}$ Le Temps (4 Dec. 1938) claimed that the British press 'unanimously approves' the attitude assumed by the French government in light of the Italian demands. Corbin described the tone of the British press as one that 'we can consider as very satisfactory', Corbin to Bonnet, 3 Dec. 1938, MAE, Série Z, Italie, no. 309. ${ }^{54}$ For example, Pertinax (André Géraud), writing in the Journal des débats, politiques et littéraires, 17 Dec. 1938. ${ }^{55}$ Daily Herald, editorial, 17 Dec. 1938.

${ }^{56}$ Duff Cooper, Evening Standard, 6 Dec. 1938; Vansittart minute (for Halifax), 19 Dec. 1938, TNA, FO 371/22922/C358/281/17.

${ }^{57}$ Fraser to Phipps, 22 \& 23 Dec. 1938, TNA, CAB 21/555.

${ }^{58}$ Bonnet, to the Foreign Affairs Committee of the French Chamber of Deputies, 14 Dec. 1938, cited in Anthony Adamthwaite, France and the Coming of the Second World War, 251.
} 
The 'war scare' of January 1939 stemmed from intelligence that Hitler might, contrary to previous assumptions, aim 'an overwhelming blow at the Western Powers'. ${ }^{99}$ These rumours exacerbated fears of French isolationism, adding weight to French pressure for conscription. Indeed, it has been suggested that 'bogus information provided by the French authorities via the Paris Embassy' contributed to British fears of a German attack in the west. ${ }^{60}$ For Paris, the British decision in December to implement only a voluntary system of national service was inadequate, not only lacking an element of compulsion but also focusing on passive defence rather than an expeditionary force. When Corbin raised this concern, William Strang, head of the foreign office central department, retorted: 'it was quite impossible for us in any immediate future to provide equipment for any larger land contribution than we had at present envisaged'. This echoed the current position of the cabinet, where Halifax's arguments in favour of compulsion failed to shake Chamberlain's conviction that 'there could be, in fact, no possibility of Britain landing a large army on the continent'. ${ }^{61}$

Nonetheless, the 'war scare' impelled the foreign office to re-evaluate the benefits of conscription. Vansittart needed little persuading, reminding Halifax 'that AngloFrench relations will be in severe danger and the capacity of French resistance will rapidly be exhausted unless we greatly increase our military contribution'. ${ }^{62}$ Again, Vansittart's views were supported by news from Paris. As Dockrill has noted, French lobbying of 'Colonel W. S. Pilcher and Kenneth de Courcy, newspaper proprietor and secretary of the imperial defence league, when they visited Paris in January' fuelled fears of potential French isolation. ${ }^{63}$ Indeed, Pilcher and de Courcy's report noted how Alexis Léger, secretary-general at the Quai d’Orsay, 'related almost the whole of French foreign policy to the question of what contribution of a military character Great Britain might be

\footnotetext{
${ }^{59}$ Cabinet Committee on Foreign Policy, 19 Jan. 1939: 'Possible German Intentions', TNA, FO 371/22961/C939/15/18.

${ }^{60}$ Glyn Stone, 'From Entente to Alliance: Anglo-French relations, 1935-1939', in Alan Sharp and Glyn Stone (eds.), Anglo-French Relations in the Twentieth Century: Rivalry and Cooperation, (London: Routledge, 2000), 195. For more on the 'war scares', see Martin S. Alexander, 'Les réactions à la menace stratégique allemande en Europe occidentale: La Grande-Bretagne, la Belgique et le "cas Hollande", décembre 1938 février 1939', Cabiers d'Histoire de la Seconde Guerre Mondiale, 7 (1982), 5-38.

${ }^{61}$ Strang to Phipps, 28 Jan. 1939, TNA, WO 208/2037A; Cabinet Committee on Foreign Policy, 23 Jan. 1939, TNA, CAB 27/264.

${ }^{62}$ Vansittart minute (for Halifax), 24 Jan. 1939, TNA, FO 371/22922/C940/28/17.

${ }^{63}$ Dockrill, British Establishment Perspectives on France, 124.
} 
prepared to make'. ${ }^{64}$ Furthermore, both Gamelin and the military governor of Strasbourg, General Pierre Héring, spoke in the same terms to Hore-Belisha during the latter's visit to the Maginot Line that same month. ${ }^{65}$ Such reports confirmed the conclusion already reached by the Chiefs of Staff: 'France's survival as a European power is conditional upon her being able to count on Britain's support in any contingency that may arise'. ${ }^{66}$ Consequently, they advocated an increase in the size of the BEF as well as full staff talks between the two countries.

For Paris, this provided another opportunity to emphasise 'that recourse to conscription is the essential element of an effective British contribution to common defence'. ${ }^{67}$ Nonetheless, a Quai d'Orsay note acknowledged that British public demand for conscription was not yet overwhelming, and that the hostility of certain sections of British opinion remained problematic. Even those newspapers most explicitly in favour of augmenting the army, notably the Daily Express and the Yorkshire Post, were wary of overtly advocating conscription. In the present climate of opinion, concluded the Quai d'Orsay 'it would be vain to hope that ... the British government will spontaneously take the initiative' ${ }^{68}$ Their conclusion was borne out by London's response to a French aidemémoire of 1 February that again implored the introduction of conscription. Strang simply suggested that the reference to conscription 'should be ignored'. Nonetheless, he acknowledged that Britain's attitude required re-evaluation. The longstanding reluctance to commit to France, he remarked, had been based on the policy of 'no more commitments' and a latent distrust of France. However, 'these days have now long passed', and a failure to commit to France might push sections of French opinion towards advocating the abandonment of existing commitments, including obligations to Britain. Cadogan concurred, and wanted to reassure the French: 'I know all the objections about "putting our foreign policy in the hands of the French Govt." But again, in these days, is there much risk in that? ${ }^{69}$

Under considerable pressure, Chamberlain informed the Commons on 6 February that 'any threat to the vital interests of France from whatever quarter it came

\footnotetext{
${ }^{64}$ Notes for Cadogan on the visit of Pilcher and de Courcy to Paris, 27 Jan. 1939, TNA, FO 371/22922/C1983/281/17. Léger's expressed similar opinions to Earl de la Warr: 'Note for the Secretary of State', 5 Feb. 1939, Churchill Archives Centre (CAC), Cambridge, Phipps Papers, PHPP I 5/7. ${ }^{65}$ Dockrill, British Establishment Perspectives on France, 125.

${ }^{66}$ A general staff paper of 7 Jan. 1939, cited in Imlay, 'The Making of the Anglo-French Alliance', 110.

${ }^{67}$ Note, Directeur politique, 29 Jan. 1939, MAE, Papiers 1940: Cabinet Georges Bonnet, no. 2.

${ }^{68}$ Note - conscription en Angleterre (le sous-directeur d'Europe), 30 Jan. 1939, MAE, Papiers 1940:

Papiers Rochat, no. 18.

${ }^{69}$ French aide-mémoire for the British government, 1 Feb. 1939, TNA, FO 371/22963/C1318/15/18, and minutes by Strang and Cadogan, both 4 Feb. 1939.
} 
must evoke the immediate co-operation of this country'. ${ }^{70}$ This declaration of FrancoBritish solidarity provoked an almost euphoric reaction in the French press, ${ }^{71}$ and certainly delighted the French government. Indeed, Bonnet had urged Corbin to impress upon Halifax the need for such a statement. ${ }^{72}$ However, the conscription decision continued to elude them, and representations of British public opinion dissuaded them from pressurising London too strongly. Corbin warned that significant sections of British opinion continued to feel the 'greatest repugnance' towards conscription, ensuring that the government would encounter 'very serious difficulties on the day it decides to establish it in peacetime'.73 Although Corbin's appraisal was doubtless influenced by the persistent hostility of the British left, it was the lack of explicit support for compulsory service that was most worrying. In early 1939, calls for the introduction of conscription were barely evident in the British press, with most newspapers content to await the outcome of the voluntary system. Indeed, the only newspapers consistently in favour of conscription - the Evening Standard and Daily Express - were equally voluble in espousing isolationism. ${ }^{74}$ Furthermore, as tensions created by the 'war scare' began to dissipate, political support for conscription diminished and the issue faded into the background. However, this was to dramatically change in March, as Hitler's manoeuvrings in Central Europe fundamentally altered the diplomatic landscape.

The German occupation of Bohemia and Moravia in March 1939 destroyed most remaining illusions regarding appeasement, and both British and French opinion demanded a firm response. Public disillusionment with appeasement had been evident for several months - at least since Munich - but it was the events of March 1939 that crystallized opinion. With appeasement seemingly defunct, Britain had to demonstrate a determination to halt Nazism by force, proving that she was both able and willing to uphold the guarantees provided to Poland, Greece and Romania in the immediate aftermath of the Prague coup. Conscription was increasingly seen as an ideal gesture. As

\footnotetext{
70343 H. C. Deb. 5s, col. 623.

${ }^{71}$ For example, Pierre Brossolette in Le Populaire, 7 Feb. 1939, Gabriel Péri in Humanité, 7 Feb. 1939, Pierre Bernus in the Journal des débats, politiques et littéraires, 8 Feb. 1939, and Le Temps, 'La solidarité de la France et de l'Angleterre', 7 Feb. 1939.

72 Bonnet to Corbin, 5 Feb. 1939, Documents Diplomatiques Français (DDF), 2nd ser., XIV, no. 40.

${ }^{73}$ Corbin to Bonnet, 7 Feb. 1939, DDF, 2nd ser., XIV, no. 65.

${ }^{74}$ The Daily Express (20 Feb. 1939) stated that the country 'is utterly opposed' to the idea of sending an army to the continent.
} 
Hore-Belisha noted on 28 March: 'Recent events had convinced me that we would have to have conscription'. ${ }^{75}$ Similarly, Cadogan was persuaded that 'we must do something about our military strength [...] it is the test by which other countries (including Germany) will judge. ${ }^{76}$

Greater cabinet support encouraged Halifax, who had argued back in February that conscription 'will have a tremendous moral effect in France.' ${ }^{77}$ After the Prague coup, reports from the Paris embassy indicated that the French clamour was intensifying. ${ }^{78}$ Indeed, French newspapers joining the chorus for conscription to an unprecedented extent, ${ }^{79}$ whilst German and Italian newspapers mocked the british public's unwillingness to embrace compulsory military service. André François-Poncet, the French ambassador in Rome, reported how the Italian press consistently highlighted the lack of British conscription, an observation echoed by his British counterpart, Lord Perth. On 31 March, the latter cited an article from the previous day's Tribuna: 'Arms, guns, pounds, aeroplanes, the home fleet, yes; conscription, no'.

The foreign office was evidently persuaded that British conscription would have a profound effect on the dictators, one official suggesting that 'national service is the best weapon we can use to impress Mussolini that we mean business'. However, potential domestic repercussions remained troubling, and the left's attitude was increasingly exasperating those in favour of conscription. As another foreign office official lamented: 'the people who are loudest in the demand for strong action refuse to take the one measure calculated to annoy and confound the dictators. Even Russia, which is held up as the pattern of democracy, has undemocratic compulsory service'. ${ }^{81}$ The persistent hostility of the British left compelled Corbin to remind Paris that whilst compulsory service was an unquestioned French tradition, 'the psychological atmosphere is not the same' in Britain. ${ }^{82}$ This contrasting 'psychological atmosphere' alarmed the French left.

\footnotetext{
75 Diary entry for 28 Mar. 1939, in R. J. Minney, ed., The Private Papers of Hore-Belisha, (Aldershot: Gregg Revivals, 1991), 187.

${ }^{76}$ Diary entry for 28 Mar. 1939, in David Dilks, ed., The Diaries of Sir Alexander Cadogan, 1938-45, (London: Cassell, 1971), 164.

${ }^{77}$ Halifax, 'Strategic Position of France in Relation to the Rôle of the British Army in War', 17 Feb. 1939, TNA, FO 371/22922/C2192/281/17.

${ }^{78}$ Phipps to Halifax, 16 Mar. 1939, TNA, FO 371/22993/C3227/19/18.

${ }^{79}$ For example, La République, 21 Mar. 1939; Intransigeant, 24 \& 29 Mar. 1939.

${ }^{80}$ François-Poncet to Bonnet, 29 Mar. 1939, MAE, Série Z, Allemagne, no. 724; Perth to Halifax, 31 Mar. 1939, TNA, FO 371/23076/C4593/3778/18.

${ }^{81}$ Minutes by Roberts and Kirkpatrick, both 4 Apr. 1939, TNA, FO 371/23076/C4593/3778/18.

${ }^{82}$ Corbin to Bonnet, 29 Mar. 1939, DDF, 2nd ser., XV, no. 195.
} 
As Phipps noted, 'to the French Trade Unionist, as to all his compatriots, the idea that conscription should be undemocratic is impossible to grasp. ${ }^{83}$

On the British right, however, recourse to conscription was increasingly advocated. On 29 March thirty Conservative dissidents, including Churchill and Duff Cooper, tabled a motion calling for conscription to be introduced ${ }^{84}$ Several days earlier, the 1922 Committee had expressed support for compulsory service, a fact not lost on Corbin. ${ }^{85}$ For Paris, these signs offered hope that a favourable decision was imminent. However, the British continued to emphasize that implementing conscription would be problematic; Halifax informed Bonnet of 'the difficulties arising and how grave might be the repercussions on the whole strength and capacity of this country if they were rudely handled, ${ }^{86}$ London's anxieties were understandable given the voluble hostility of the farleft. The communist Daily Worker questioned the need for conscription in predictably evocative and ideologically-motivated rhetoric: 'Service for the traitors who have built up Hitler and Mussolini to the point where they can kill more British workers than the Kaiser killed on the Somme? Service for the Labour leaders who have backed these traitors? ${ }^{87}$

This latter point, however, illustrates that leftist opposition was not unanimous. Indeed, there was a clear distinction between, on the one hand, the more militant trade unions and the communists, and on the other, the leadership of both the Labour Party and the TUC. Certainly, much of the trade union and Labour opposition lacked conviction. As Hugh Dalton later acknowledged, 'I did not believe that there was much deep-seated opposition to conscription' ${ }^{88}$ Furthermore, prominent figures within the Labour movement attempted to change attitudes within the Parliamentary Labour Party (PLP). As Douglas Jay recalled, he and Hugh Gaitskill feared that the PLP would 'make a fool of itself by demanding resistance to Hitler and voting against conscription at the same time'. Consequently, they 'devised a scheme to avert this, and successfully sold it to Dalton' ${ }^{89}$ This scheme focused on winning the Labour leadership's support for conscription in exchange for a quid pro quo by way of the conscription of wealth.

\footnotetext{
83 Phipps to Halifax, 4 Apr. 1939, TNA, FO 371/22909/C5010/25/17.

${ }^{84}$ Crowson, Facing Fascism, 164-5; Dennis, Decision by Default, 198.

${ }^{85}$ Corbin to Bonnet, 22 Mar. 1939, MAE, Série Z, Allemagne, no. 724.

${ }^{86}$ Despatch to the chargé d'affaires in Paris, regarding conversation between Halifax and Bonnet, 23 Mar. 1939, TNA, FO 800/311.

87 Daily Worker, editorial, 29 Mar. 1939.

${ }^{88}$ Hugh Dalton, The Fateful Years: Memoirs, 1931-1945, (London: Frederick Muller Ltd., 1957), 254.

${ }^{89}$ Douglas Jay, Change and Fortune: A Political Record, (London: Hutchinson, 1980), pp. 78-9. See also

Richard Toye, 'The Labour Party and the Economics of Rearmament, 1935-39', Twentieth Century British History, Vol. 12, no. 3 (2001), 303-26.
} 
Although Dalton and Attlee accepted the logic of this argument, the Labour leader was unable to sell the scheme to the PLP. ${ }^{90}$ Nevertheless, residual leftist opposition was overshadowed by the increasingly voluble campaign in favour of conscription. ' $\mathrm{f} f$ the country decides that it must have conscription', argued the Daily Mail, 'then for Heaven's sake let us have conscription now! ${ }^{91}$ For French officials in London, public demand for conscription had reached new heights. As Lelong noted, 'the idea of obligatory service has made notable progress'. More importantly, Corbin remarked how the campaign had assumed a very different character from that experienced after Munich. The inadequacies of the voluntary system had been exposed; compulsion was now being explicitly advocated. $^{92}$

Within the French press, both the Paris-Midi and Le Temps detected an evolution of British opinion in favour of obligatory service, as did Pertinax, who urged the British to bite the bullet: 'Courage, M. Britling, acceptez la conscription et la paix sera sawvée'.

Furthermore, the French left abandoned their previous reluctance to condemn their British counterparts. The communist Ce Soir questioned the confidence one could have in British firmness against the dictators whilst they refused recourse to compulsory service. ${ }^{93}$ The tone of the French press did not go unnoticed by British newspapers, with the Daily Mail, the Observer and the Sunday Times all noting that the French were anxious for Britain to introduce conscription without delay. Most tellingly, the isolationist Daily Express conceded that the current situation permitted them 'to accept the alliance with France as something compatible with Isolation'. Indeed, isolation could be extended to the Maginot Line, "to become what may be called "Bisolation". ${ }^{94}$

In such a context, Michael Howard's appraisal of the decision taken at the end of March to double the size of the Territorial Army from 13 to 26 divisions - that it was 'a response to the public mood, and as such was welcomed by virtually everyone' - is indisputable. ${ }^{95}$ However, as Phipps reported, the French were unimpressed, and calls for conscription remained 'a commonplace of any newspaper article or conversation, and was, I learned, impressed yesterday upon British journalists at the Ministry of Foreign

\footnotetext{
${ }^{90}$ L. V. Scott, Conscription and the Attlee Governments: The Politics and Policy of National Service, 1945-1951, (Oxford: Oxford University Press, 1993), 5.

${ }^{91}$ Duff Cooper, Evening Standard, 28 Mar. 1939; Daily Mail, editorial, 18 Mar. 1939.

${ }^{2}$ Lelong to Daladier, 24 Mar. 1939, DDF, 2nd ser., XV, no. 152; Corbin to Bonnet, 29 Mar. 1939, DDF, 2nd ser., XV, no. 195.

93 Paris-Midi, 14 Apr. 1939; Le Temps, 24 Apr. 1939; Pertinax, Ordre, 24 Apr. 1939 ; Paul Nizan, Ce Soir, 14 Apr. 1939.

${ }_{94}$ Daily Mail, editorial, 21 Apr. 1939; Observer, Paris correspondent, 23 Apr. 1939; Sunday Times, Paris correspondent, 9 Apr. 1939; Daily Express, editorial, 30 Mar. 1939.

${ }^{95}$ Howard, The Continental Commitment, 129.
} 
Affairs'. Several days later, Phipps informed London of 'grumbling in the provinces no less than in Paris; and feeling is so strong that it might affect French morale in a future crisis'. In late April, a report from the British consulate in Strasbourg noted how 'local criticism of Great Britain ebbs and flows in proportion to press reports on the imminence of our adoption of conscription'. ${ }^{96}$ Although Chamberlain appeared relatively unconcerned by French opinion, his cabinet could not be ignored. 'Our people', he remarked, 'were getting very worked up about conscription', although he himself 'came down flat footed against it. ${ }^{97}$ On 18 April, Hore-Belisha recorded how Chamberlain accused him of having 'a bee in my bonnet about conscription'. ${ }^{98}$ However, Chamberlain was finding himself increasingly isolated. Paris thus sensed that the tide had turned, and that one last push would suffice for the British to finally succumb.

\section{VI}

By April 1939, as Roger Broad has observed, 'increasing restiveness in France about British policy demanded more positive action'. ${ }^{99}$ On 18 April, Daladier informed Phipps in no uncertain terms of his desire to see conscription implemented in Britain, arguing that it would have a 'propitious effect in France', as well as furnishing 'an excellent argument for the political negotiations with the USSR'. The following day, pressure emerged from another quarter when the American ambassador in Paris, William Bullitt, told Phipps that President Roosevelt 'felt very strongly that it was absolutely essential' that conscription is introduced. ${ }^{100}$ 'The French are pressing us strongly' noted Oliver Harvey, Halifax's private secretary, 'and we hear that even Roosevelt is dismayed that we haven't yet taken this step'. ${ }^{101}$ By the time the former secretary of the Committee of Imperial Defence, Sir Maurice Hankey, suggested that 'the French are a little overdoing the pressure about National Service ${ }^{, 102}$, Chamberlain had already decided to introduce a form of conscription. In a letter to his sister he applauded himself for correctly

\footnotetext{
${ }^{96}$ Phipps to Halifax, 12 Apr. and 14 Apr. 1939, TNA, FO 371/23077/C5132/3778/18; Report from the British Consulate at Strasbourg, 26 Apr. 1939, TNA, FO 371/22909/C6506/25/17.

${ }^{97}$ Neville to Hilda Chamberlain, 2 Apr. 1939, Chamberlain Papers, University of Birmingham, Special Collections Department, NC 18/1/1092.

${ }^{98}$ Minney, ed., The Private Papers of Hore-Belisha, 196.

${ }^{99}$ Roger Broad, Conscription in Britain, 1939-1964: The Militarisation of a Generation, (Abingdon: Routledge, 2006), 90.

${ }^{100}$ Notes manuscrites d'Édouard Daladier, AN, Fonds Daladier, 496 AP/10, 2 DA 5 Dr. 5, sdrd; Phipps to Halifax, 20 Apr. 1939, CAC, Phipps Papers, PHPP I 1/22.

101 Diary entry for 19 Apr. 1939, in John Harvey, ed., The Diplomatic Diaries of Sir Oliver Harvey 1937-1940, (London: John Harvey, 1970), 281.

102 Hankey to Phipps, 24 Apr. 1939, CAC, Phipps Papers, PHPP I 3/3.
} 
interpreting the mood of the people: 'I believe we hit on the right moment when public opinion was ripe for the move and when the foreigners would not have been satisfied to wait for it much longer'. ${ }^{103}$

Why Chamberlain finally succumbed in April 1939 remains contentious.

Evidently, the combination of French and domestic pressure had intensified considerably during the autumn and winter of 1938-39, and the introduction of conscription certainly did give Chamberlain a respite. ${ }^{104}$ However, military considerations must not be overlooked. As Len Scott has noted, 'the government, and particularly Chamberlain, became obsessed with the fear of a sudden German knockout blow from the air'. ${ }^{105}$ After the Prague coup, Chamberlain viewed conscription as a necessary instrument for augmenting Britain's anti-aircraft defences. Nevertheless, one cannot imagine that Chamberlain would have taken such a step were it not for the fusion of French and domestic pressure.

The need to reassure Paris was certainly pivotal in the British decision. As Cadogan noted, when Phipps informed the French of the news ' $t$ they burst into tears and flung their arms round his neck and agreed to anything we liked! ${ }^{106}$ Of course, public support for conscription was not unanimous, and the government anticipated considerable difficulties in implementing it. In justifying the decision before the trade unions it was argued that 'the march of events' - which included 'pressure from the French, as well as from almost all quarters of Europe' - had made it 'impossible any longer to neglect this further means of strengthening our defences'. ${ }^{107}$ Nevertheless, opposition was unavoidable, reflecting the deep-rooted hostility of many on the left. The Daily Herald deplored how: 'without reference to public opinion, without consultation of any kind, conscription is imposed upon the country'. The Daily Worker was predictably more explicit, condemning conscription as 'a way of fighting the British working-classes while the British ruling-classes make a deal with Hitler'. ${ }^{108}$

Leftist dissent was also voiced in parliament. Chamberlain tried to pre-empt criticism from the left by citing the French Communist, Gabriel Péri: 'It is impossible to contest the importance of the British decision', Péri had written, 'As long as this decision

\footnotetext{
103 Neville to Hilda Chamberlain, 29 Apr. 1939, Chamberlain Papers, NC 18/1/1096.

104 Broad, Conscription in Britain, 1939-1964, 93.

105 Scott, Conscription and the Attlee Governments, 2. For more on the fear of air attack, see Uri Bialer, The

Shadow of the Bomber: The Fear of Air Attack and British Politics, 1932-1939, (London: Royal Historical Society, 1980).

106 Dilks, ed., The Diaries of Sir Alexander Cadogan, 176 (original emphasis).

107 Notes for TUC, 24 Apr. 1939, TNA, CAB 21/1264.

108 Daily Worker, editorial, 26 Apr. 1939; Daily Herald, editorial, 27 Apr. 1939.
} 
was not taken Britain's promises to Poland, Romania and Greece were of a more symbolic than practical character'. This cut little ice with the opposition. As soon as Chamberlain mentioned Péri, the sole communist MP, William Gallacher, interjected: 'I repudiate him right away'. The Labour leader, Clement Attlee, also opposed the decision. 'Far from strengthening this country', he argued, 'it will weaken it and divide it, at a time when it should be strong and united'. The Liberal leader, Sir Archibald Sinclair, was less vociferous, simply lamenting the lack of consultation with the opposition and trade unions. ${ }^{109}$ Indeed, despite traditional Liberal opposition to conscription, the party had consistently failed to adopt a coherent position, a fact reflected in the Parliamentary vote. Although seven Liberal MPs opposed the conscription bill, six lent their support. ${ }^{110}$

Overall, criticism was remarkably subdued. The Labour party arguably faced more criticism for opposing conscription than the government encountered in introducing it. The Daily Mirror described Labour's opposition as 'illogical', whilst the Observer suggested that 'a majority of the country is against them'. ${ }^{111}$ The liberal newspapers, which had previously been reluctant to express an opinion on the issue of conscription, also accepted the decision. The Manchester Guardian initially sympathised with leftist objections, but soon acknowledged that 'British conscription is now an essential component of the Peace Front in which, far more sincerely than the Government, the Opposition parties believe'. ${ }^{112}$ Sinclair echoed this view in the Commons, conceding that conscription 'has become - wrongly as I think, but I have to face the fact it has become - a symbol abroad of British strength and purpose'. ${ }^{113}$

Although Labour's opposition was more sustained, it too rapidly subsided. At the party's annual conference in Southport at the end of May, a resolution calling for noncooperation with the bill was comfortably defeated. ${ }^{114}$ Similarly, hostility among the trade union leadership quickly dissipated once the bill had been passed. As Alan Bullock has noted, although Ernest Bevin was angry that the government had 'brought in

109346 H. C. Deb. 5s, cols. 1152, 1353 and 1365, all from the debate of 26 Apr. 1939. Chamberlain was citing an article by Gabriel Péri in Humanité.

110 Chris Cook, A Short History of the Liberal Party, 1900-1976, (London: Macmillan, 1976), 123-5. Traditional Liberal hostility to conscription was evident during the First World War. See David Dutton, A History of the Liberal Party, (Basingstoke: Palgrave Macmillan, 2004), 60-4.

111 Daily Mirror, editorial, 28 Apr. 1939; Observer, 30 Apr. 1939.

112 Manchester Guardian, 'The Bill', 3 May 1939.

113346 H. C. Deb. 5s, col. 2124, from the debate of 4 May 1939.

114 The resolution was defeated by 1,670,000 to 286,000 votes. Figures taken from Ben Pimlott, Labour and the Left in the 1930s, (Cambridge: Cambridge University Press, 1977), 183. Although the impact of block voting does not allow one to deduce the opinions of the rank and file vis-à-vis conscription, a contemporary observer, R. H. S. Crossman, suggested that Labour's opposition found little support amongst the masses. 'Labour and Compulsory Military Service', The Political Quarterly, Vol. 10, no. 3 (1939), 309-21. 
conscription by the back door and tried to "put it over" on the working class', he subsequently 'exerted his influence against those who wanted the Labour movement to withdraw from all co-operation in defence preparations [and had little] patience with leftwing talk of industrial action to resist conscription'. ${ }^{115}$ Furthermore, the TUC's general secretary, Sir Walter Citrine, noted on 4 May that the 'dangerous international situation had to be borne in mind', and that the trade union movement 'was committed to adequate national defence..${ }^{116}$ Even the more militant trade unions, notably the influential Amalgamated Engineering Union (AEU), reacted ambiguously to the conscription decision and ultimately rejected protesting with industrial action. As Imlay concludes, when 'the issue of military conscription compelled AEU leaders to choose, their hostility to fascism easily took priority over their hostility to industry and the government'. ${ }^{117}$

Leftist opposition was also undermined by the criticism of French socialists. Léon Blum noted the contradiction between advocating a firmer foreign policy whilst denying Britain the strength necessary to enforce it. The trade unionist Le Peuple concurred, regretting 'that we are not in accord with the British Labour leaders'. Overall, the Paris-Midi was correct in asserting that British socialists had received 'a sharp dressing down' from all quarters of the French left. ${ }^{118}$ On the whole, the French press welcomed the conscription decision with gratitude and delight. Le Matin remarked that when French conscripts cry 'Bravo, l'Angleterre!' they speak for the whole of France. Le Figaro described conscription as 'a far-reaching material and moral gesture'. ${ }^{119}$ Phipps's appraisal - that British conscription had been 'enthusiastically welcomed by newspapers of all parties' - was no exaggeration. ${ }^{120}$ As Corbin had predicted, the decision 'will have immense reverberations across the world, particularly in France where it has been awaited with such anxiety'. In terms of Franco-British relations, the Quai d'Orsay suggested that 'The establishment of British conscription marks, at last, a new phase on the common path pursued by France and Great Britain'. ${ }^{121}$

\footnotetext{
115 Alan Bullock, The Life and Times of Ernest Bevin, vol. 1: Trade Union Leader, 1881-1940, (London: Heinemann, 1960), 637-8. Bevin continued his attempts to overcome traditional Labour hostility to conscription in the late 1940s (see Scott, Conscription and the Attlee Governments, 32-42, Frank Myers, 'Conscription and the Politics of Military Strategy in the Attlee Government', Journal of Strategic Studies, Vol. 7, no. 1 (1984), 55-73, and Alan Bullock, Ernest Bevin: Foreign Secretary, 1945-1951, (London: Heinemann, 1983), 395-400)).

${ }^{116}$ Cited in Imlay, Facing the Second World War, 215.

117 Imlay, Facing the Second World War, 334.

118 Léon Blum, Le Populaire, 27 Apr. 1939; Léon Harmel, Le Peuple, 27 Apr. 1939; Paris-Midi, 27 Apr. 1939.

${ }^{119}$ Le Matin, 27 Apr. 1939; Wladimir d’Ormesson, Le Figaro, 27 Apr. 1939.

120 Phipps to Halifax, 27 Apr. 1939, TNA, FO 371/23077/C6053/3778/18.

${ }^{121}$ Corbin to Bonnet, 26 Apr. 1939, DDF, 2nd ser. vol. XV, no. 497; Sous-directeur d'Europe, 27 Apr. 1939

- untitled document, detailing Franco-British relations, MAE, Papiers 1940, Papiers Rochat, no. 18.
} 
Ultimately, the most telling impact of the conscription decision was the positive effect it had on the French. Materially, conscription did not immediately facilitate the despatch of a larger continental force, as the majority of the new recruits were intended to man anti-aircraft defences rather than bolster an Expeditionary Force. ${ }^{122}$ Furthermore, conscription required considerable reorganisation of the British army (which was already struggling to facilitate its recent expansion) and an influx of men did not necessarily mean an increase or improvement in equipment. ${ }^{123}$ The limited scope of the bill, which applied only to those men aged 20 and 21, suggests further that it was a moral rather than a material commitment to the continent. Indeed, the key limitation of the bill was that men were only to be trained for six months, far from sufficient for furnishing a welltrained field force intended for continental despatch. Indeed, the pro-conscription newspapers were quick to criticise the limitations of the Bill, the Daily Express considering it a 'half measure', a view echoed in the Evening Standard and the Daily Mail. ${ }^{124}$

Therefore, as Roger Broad has concluded, 'the gesture was more important than the substance'. ${ }^{125}$ In terms of the impact it had on the dictators, the effects were also mixed. Although it did not deter Hitler, it was certainly a fine riposte to German and Italian allegations that Britain was only prepared to 'fight to the last Frenchman'. To be sure, even in its limited form the conscription bill satisfied much of the demand emanating from France. As the Paris-Soir remarked, 'Berlin will no longer be able to say that Britain makes war with other countries' soldiers'. ${ }^{126}$ Indeed, when defending conscription in the Commons, the prime minister remarked: 'That gibe that Britain was "ready to fight to the last French soldier" is one that has been bandied about from capital to capital. It has been becoming clearer and clearer to us that the success of our whole effort to build up a solid front against this idea of domination by force was being jeopardised by these doubts.' ${ }^{27}$

Without French pressure, it is highly unlikely that conscription would have been introduced in peacetime. However, French pressure would have been less persuasive if British public opinion had not become receptive to the idea of national service.

\footnotetext{
122 Scott, Conscription and the Attlee Governments, 6; William Philpott and Martin S. Alexander, 'The French and the British Field Force: Moral Support or Material Contribution?', The Journal of Military History, Vol. 71, no. 3, (2007), 765.

${ }^{123}$ Howard, The Continental Commitment, 130.

124 Daily Express, Evening Standard, and the Daily Mail, all from 27 Aug. 1939.

125 Broad, Conscription in Britain, 93.

126 Paris-Soir, 26 Apr. 1939, (cited in the News Chronicle, 27 Apr. 1939).

127346 H. C. Deb. 5s, col. 1347.
} 
Moreover, the French campaign interacted with their perceptions of British opinion. In two distinct moments during 1938-9 - firstly after the Munich Agreement and secondly in the immediate aftermath of the Prague coup - Paris perceived an evolution of British opinion in favour of compulsory military service. Consequently, the French government intensified their pressure on the British government to augment their continental commitment, if only by the symbolic implementation of a limited form of conscription.

The conscription 'core sample' also shows that the increased assertiveness of the French government during 1938-9 was always contingent upon their perceptions of Britain. Although France adopted a politique de fermeté independently of the British government, the representations of British press and public opinion furnished by the London embassy reassured the Daladier government that their stance enjoyed considerable support in Britain. In sum, the French policymaking elites recognised that the British public were increasingly advocating a policy of resistance over appeasement, and that they were subsequently more favourable to conscription. Arguably, neither French pressure nor public demand was sufficient in itself to force Chamberlain to abandon his opposition. However, the two factors working in tandem - a deliberate ploy on France's part - provided a compelling argument for the introduction of British conscription. 